\title{
X-linked Chronic Granulomatous Disease
}

National Cancer Institute

\section{Source}

National Cancer Institute. X-linked Chronic Granulomatous Disease. NCI Thesaurus. Code C154315.

An X-linked recessive form of chronic granulomatous disease caused by mutation(s) in the CYBB gene, encoding cytochrome b-245 beta chain. 